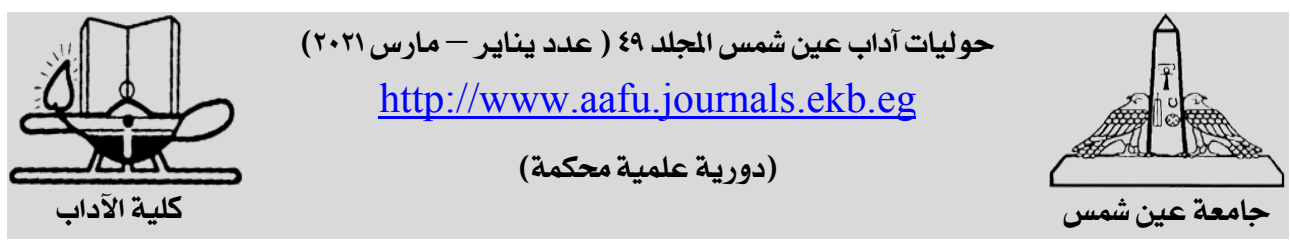

\title{
الجملة المزحزحة وجوبا في ديوان الأحوص الأصصاري
}

فاطمة عبدالرشيد محمد عبدالله

$$
\text { * قسم اللغة و النحو و الصرف- كلية اللغة العربية- جامعة أم القرى- السعودية }
$$
faabdullah@uqu.edu.sa

يهتم البحث بدر اسة الجملة المزحزحة وجوبا في ديوان الأحوص الأنصاري وهي

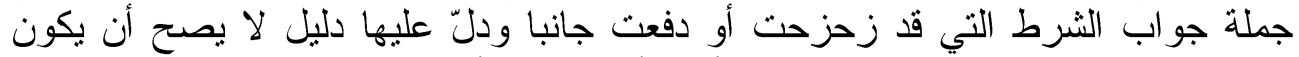

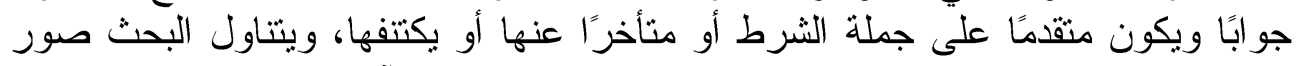

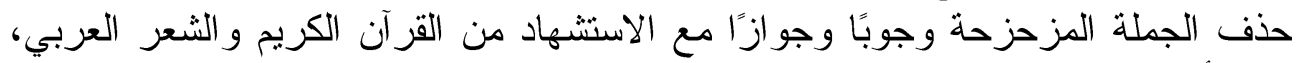

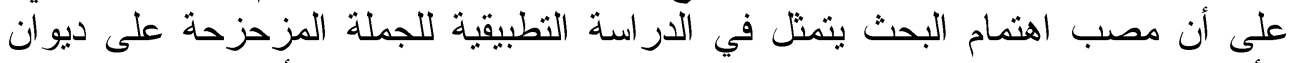

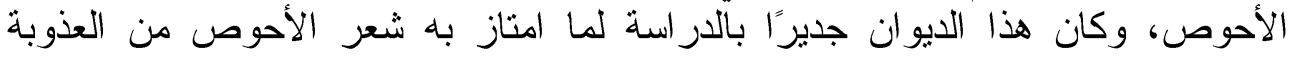
و القوة إذ أن صاحبه كان صافي الديباجة محسن في الغزل وانئ الفخر و المدح، ومن أهم نتائج

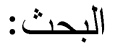

- الغرض من حذف جملة الجواب هو نرك المجال للنفس للتجول في الأشياء المكتفى بالحال عن ذكرها.

- قد يذكر مع دليل الجملة المزحزحة ما هو منرثب عليها و لا بصلح أن يكون جوابًا.

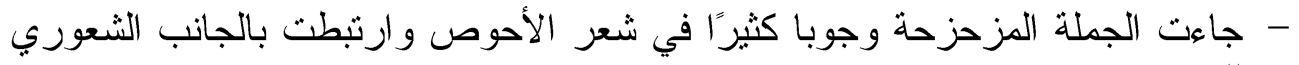
للشاعر 


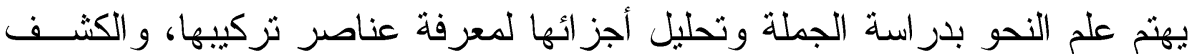

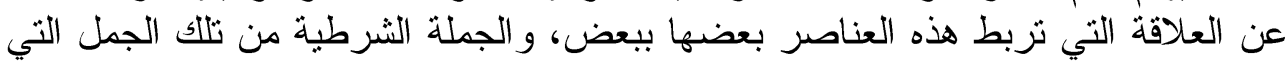

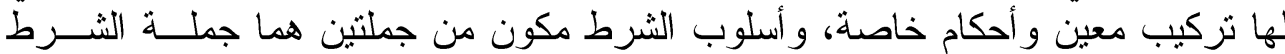

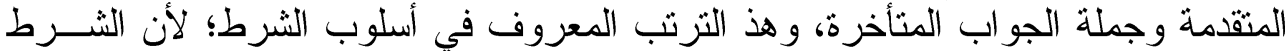

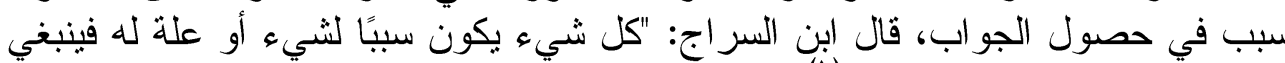

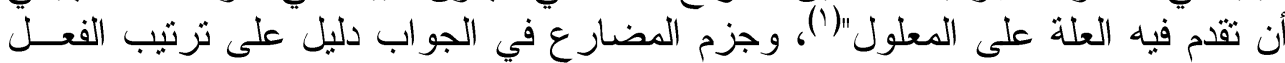

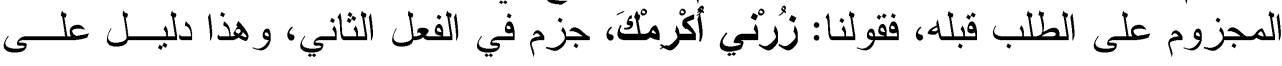

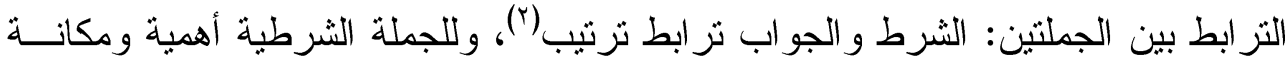

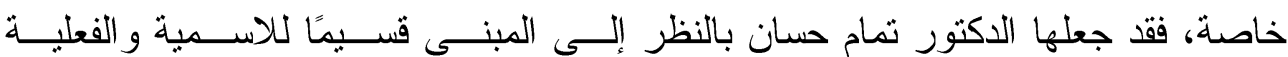

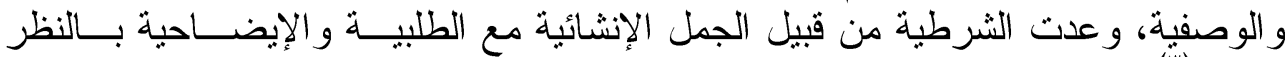

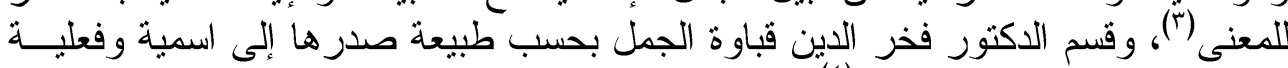

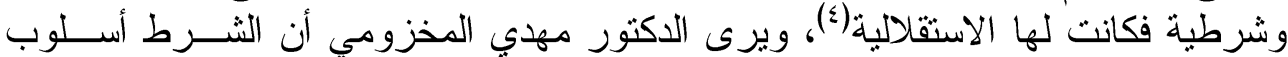

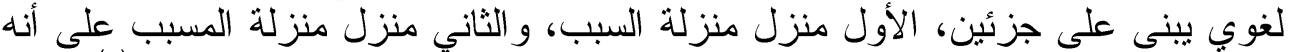

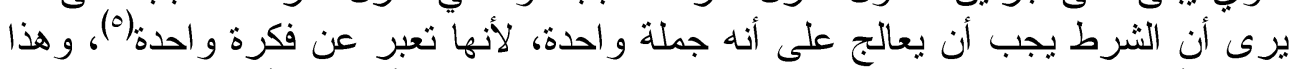

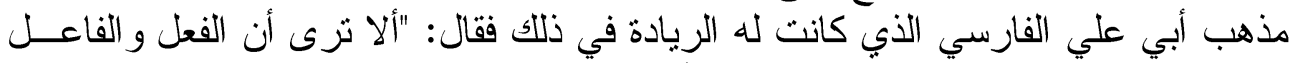

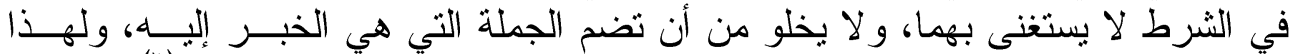

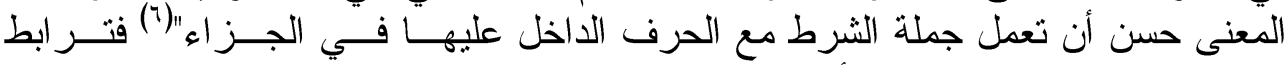

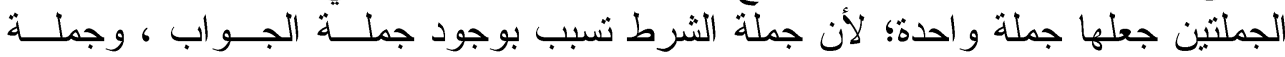

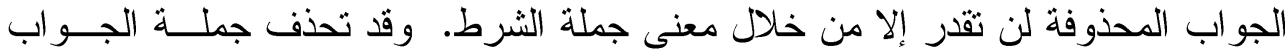

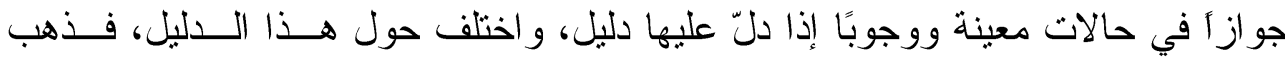

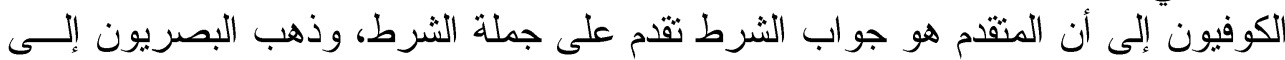
أن المتقدم دليل على جملة الجو اب المحذوفة كما سياتي.

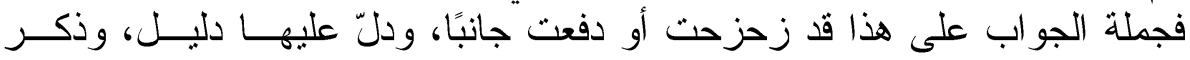

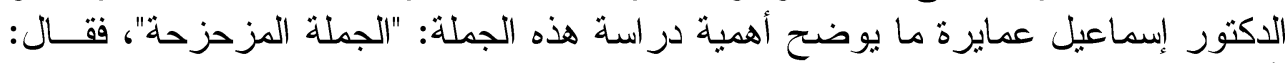

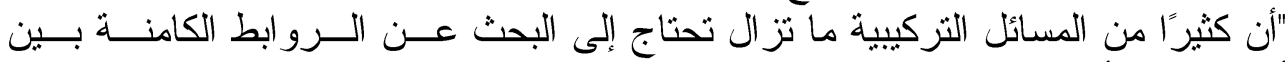

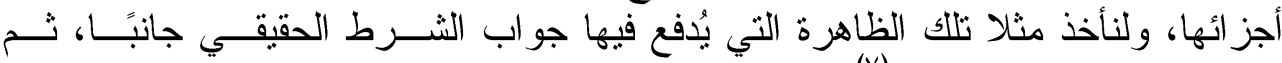

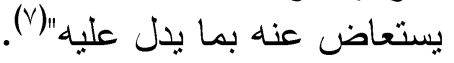

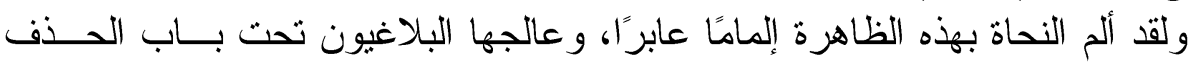

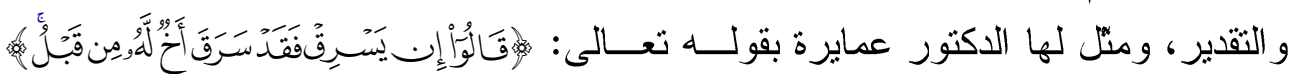

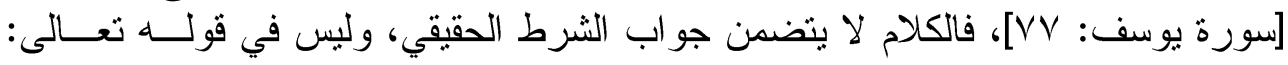

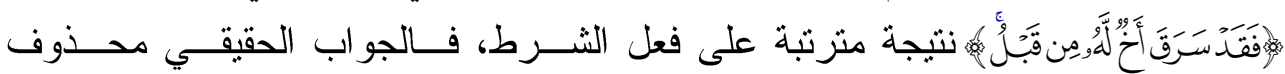

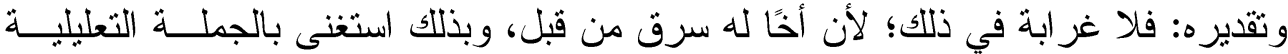

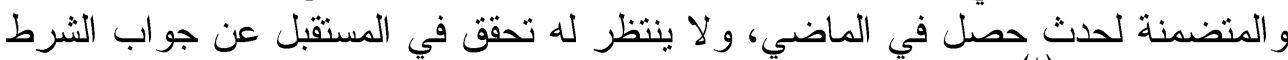

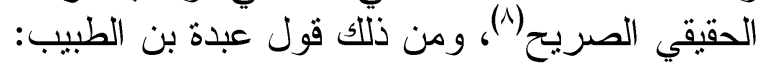
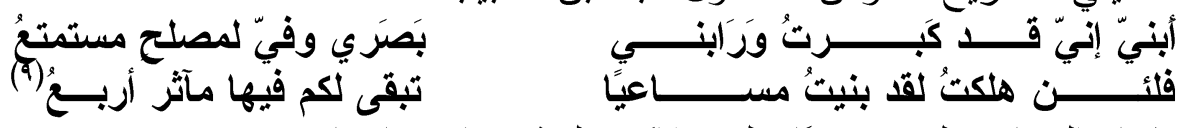

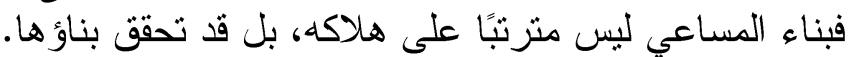


وقد لا يكون ما عوض به عن جو اب الشرط أمرًا قد تحقق و إنما هو حكمة، أو قانون نافذ

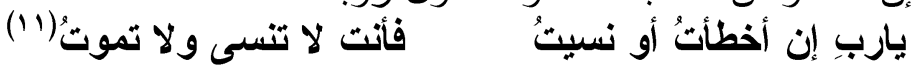

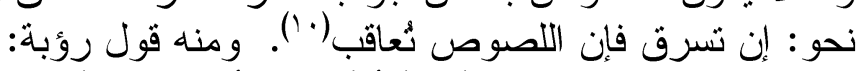

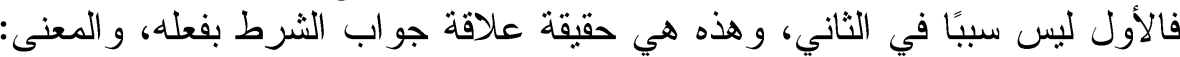

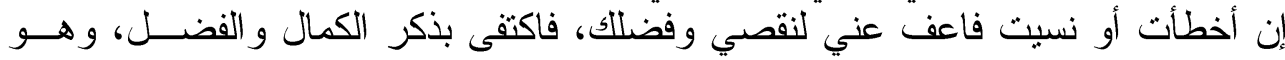
السبب من العفو وهو المسبب.

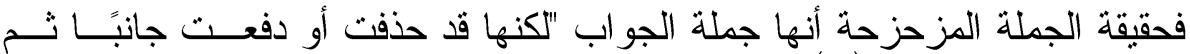

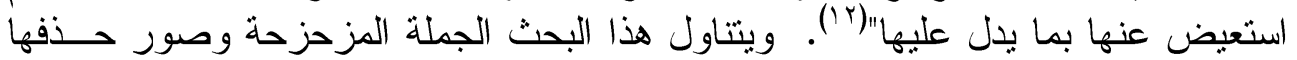

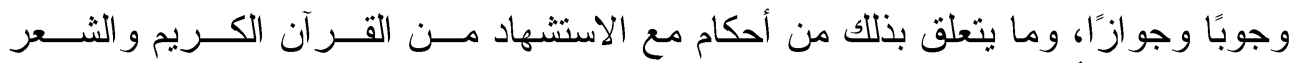

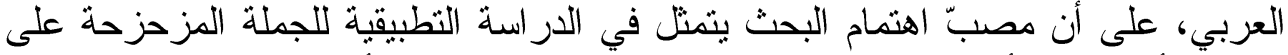

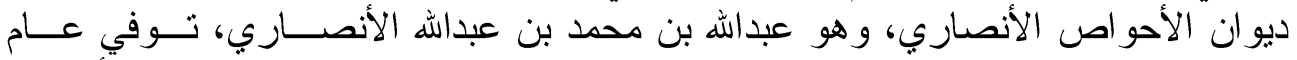

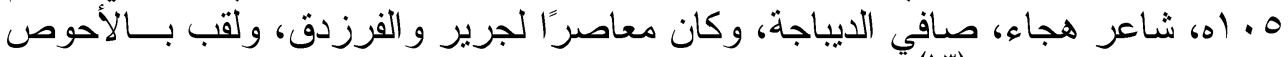

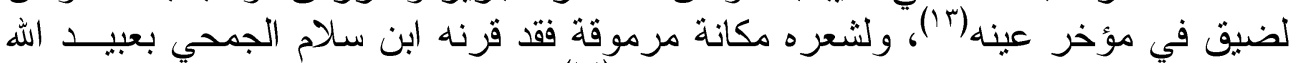

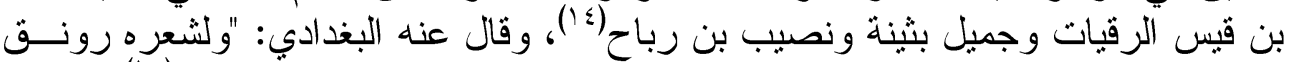

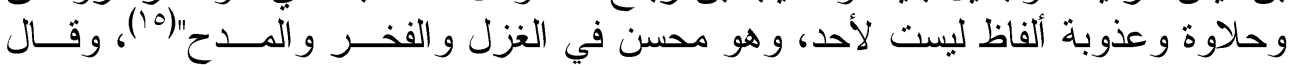

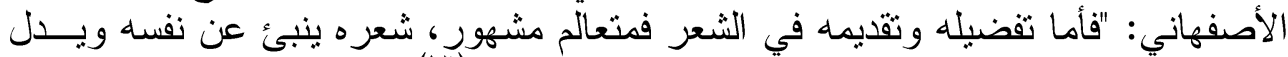

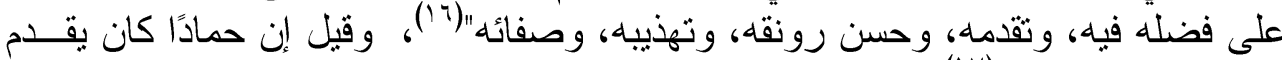

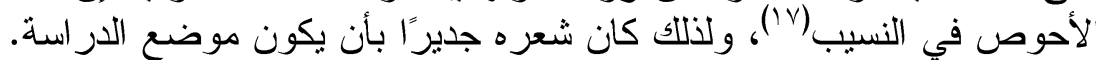

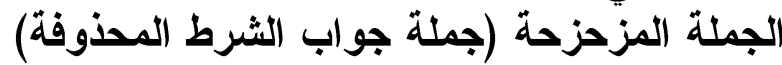
الحذف وجوبًا: الجملة المزئا

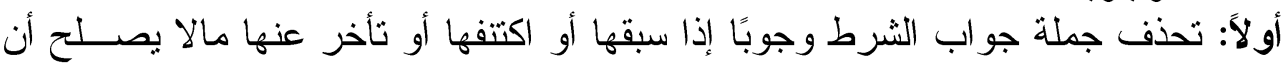

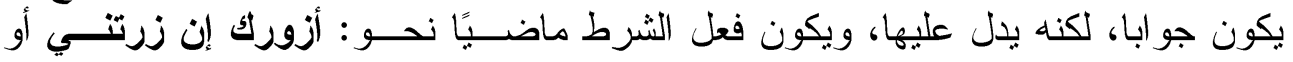

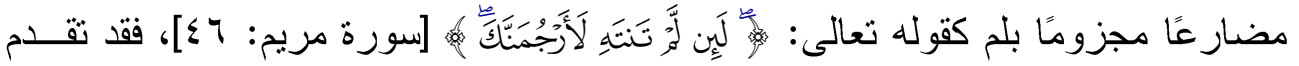

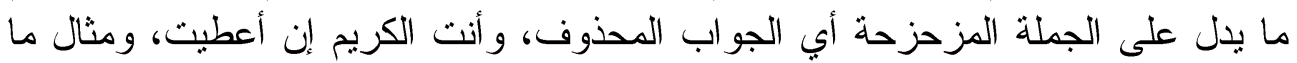

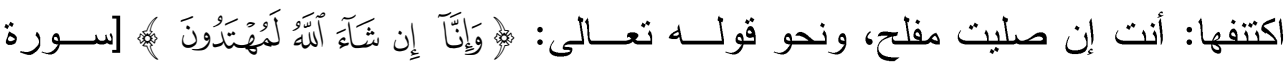

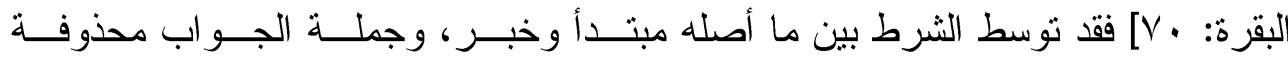

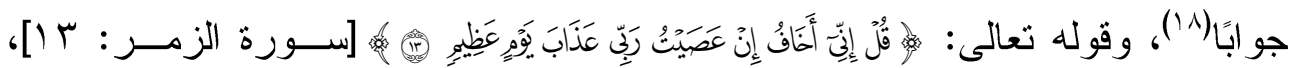

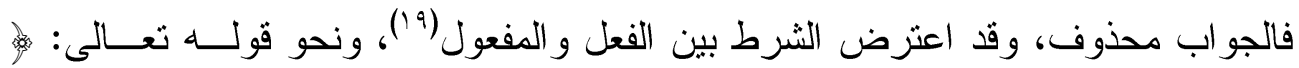

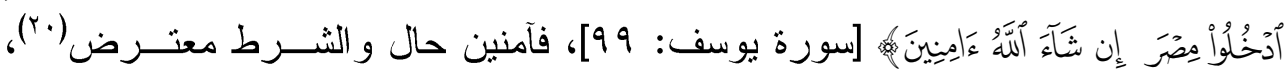

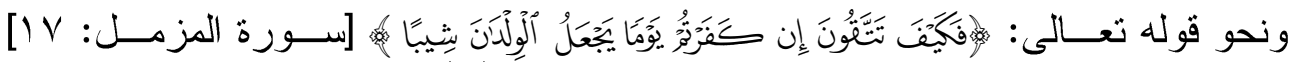

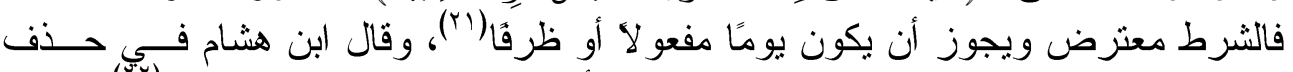

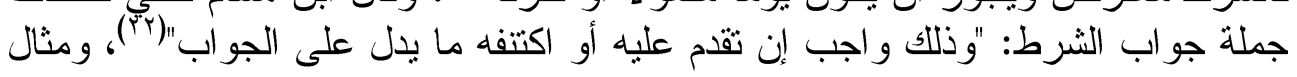

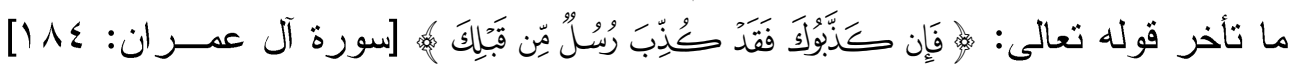

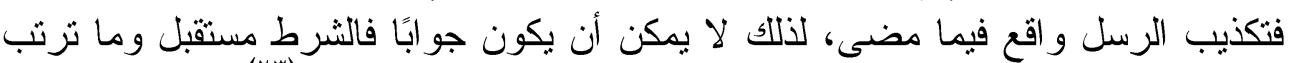

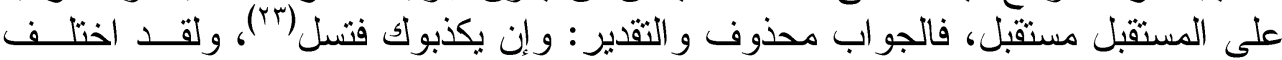

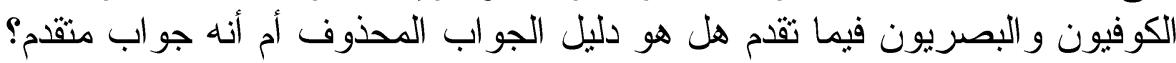




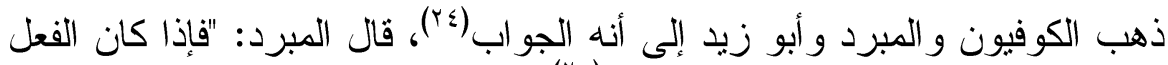

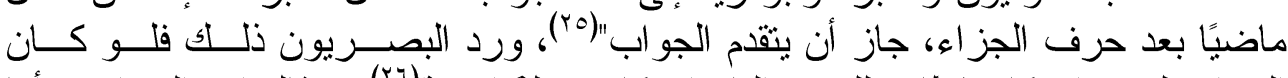

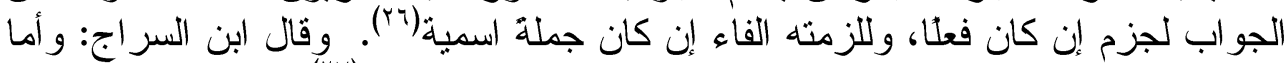

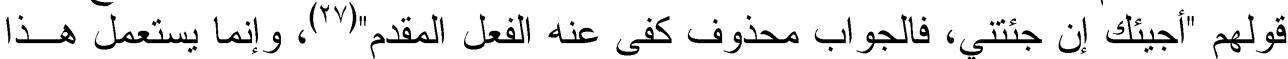

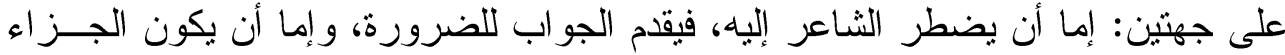

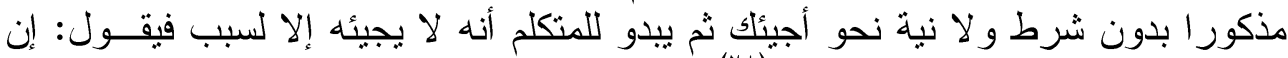

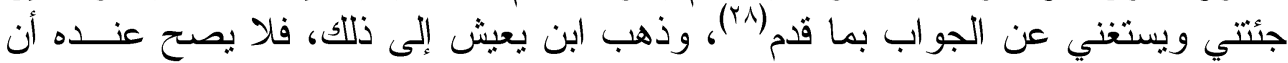

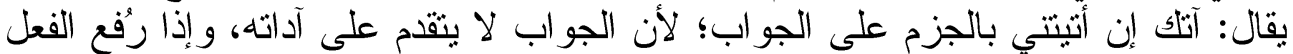

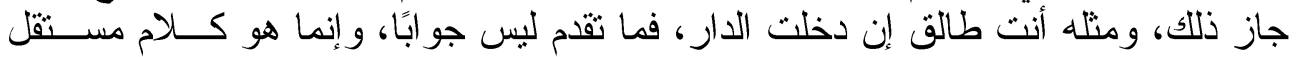

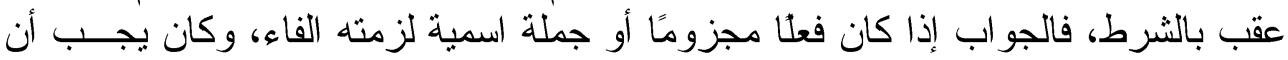

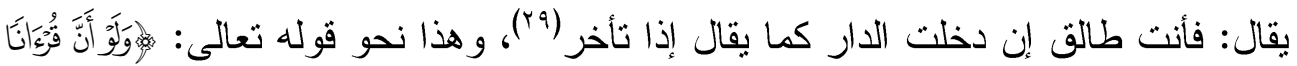

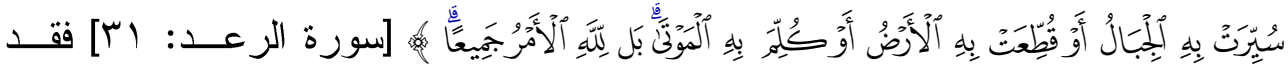

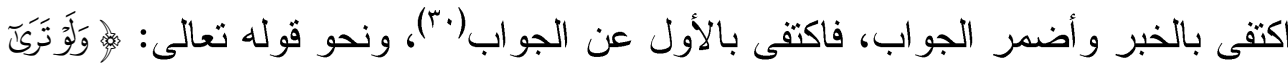

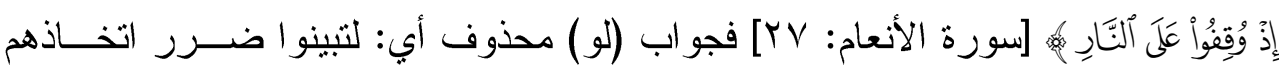

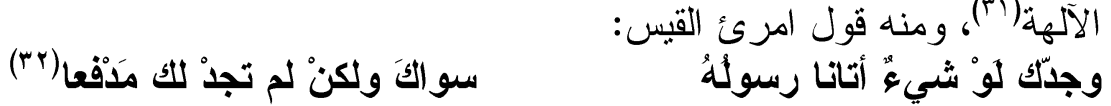

$$
\begin{aligned}
& \text { فالتقدبر : لو أتنانا رسول سو الك لدفعناه. وكقوله: }
\end{aligned}
$$

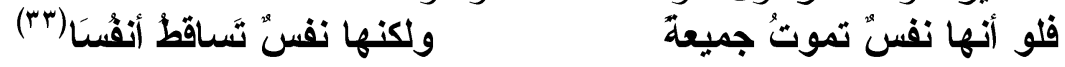

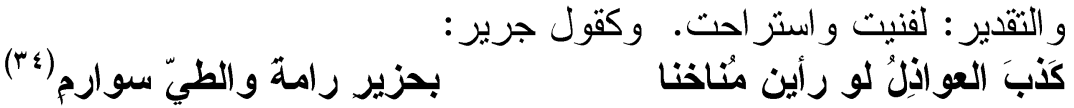

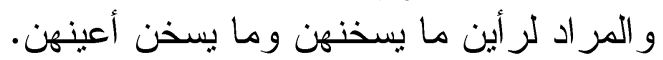

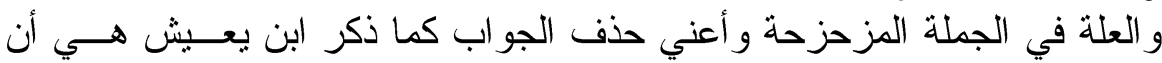

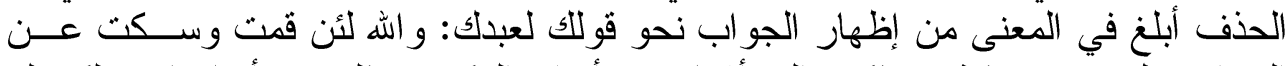

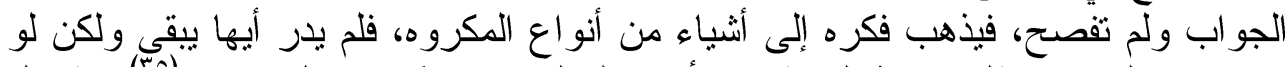

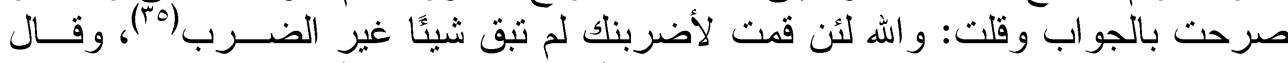
السيوطي: إنما يحسن الحذف لقوة الدالالة عليه، أو يقصد به تعديد أثنياء فيكون في تعدادها

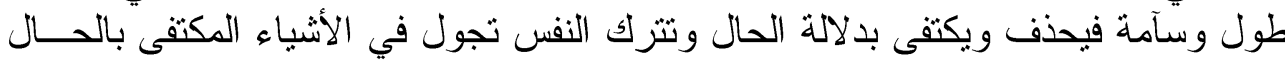

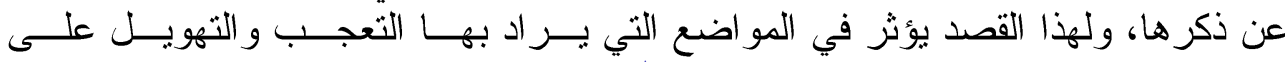

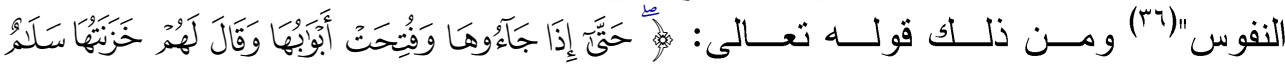

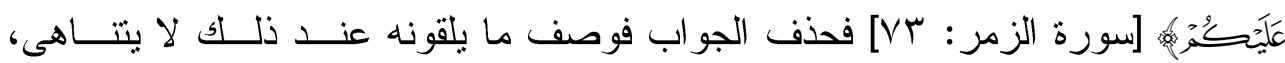

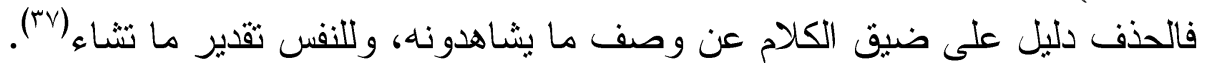

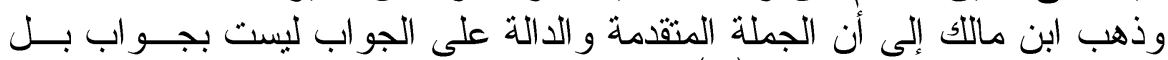

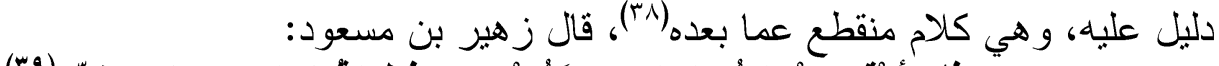

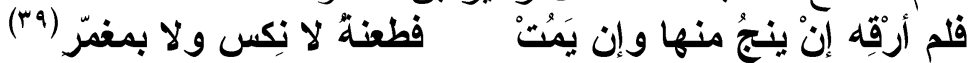

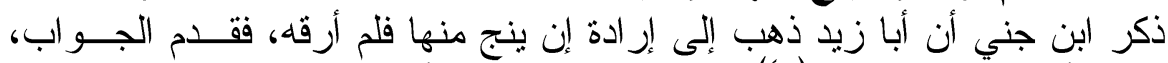

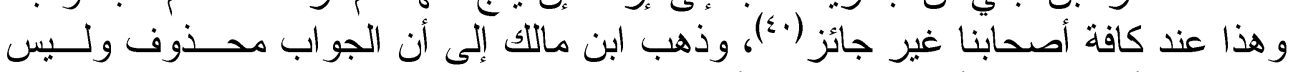

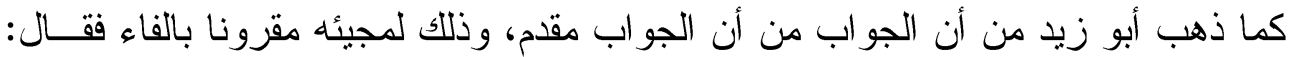

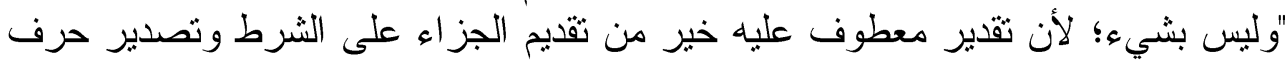




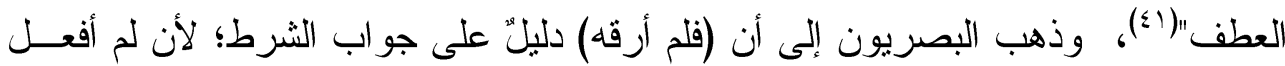

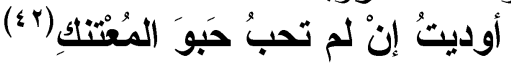

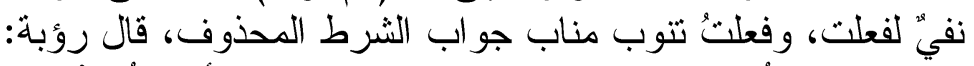

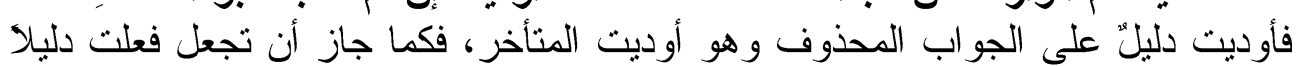

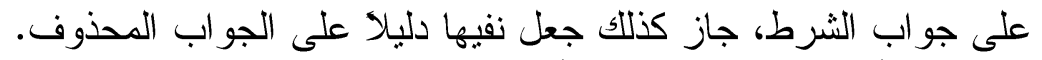

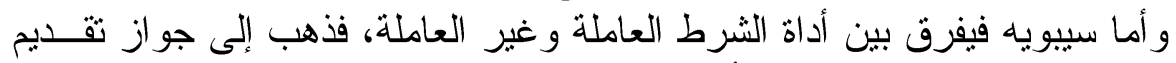

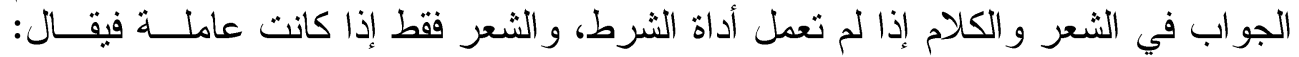

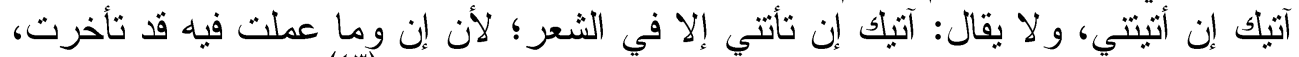

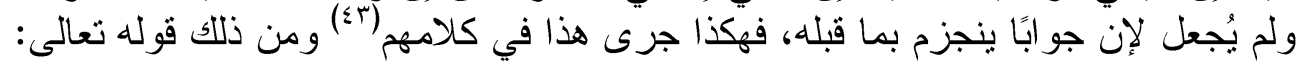

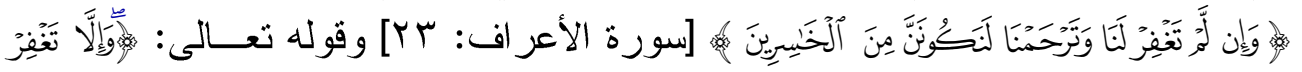

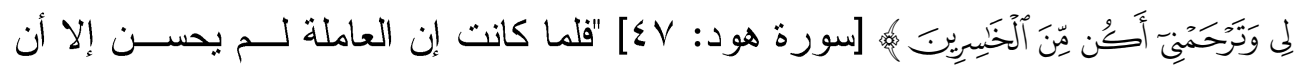

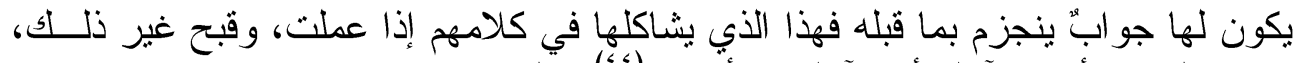

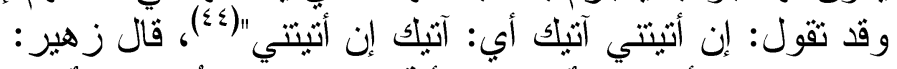

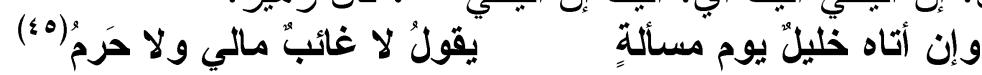

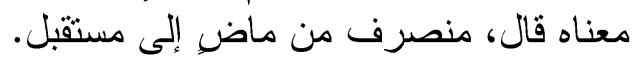
شواهد الجملة المزحزحة وجوبا بلاليل عليها من شعن شعر الأحوص:

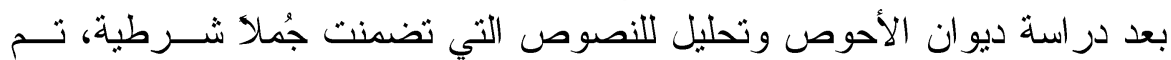

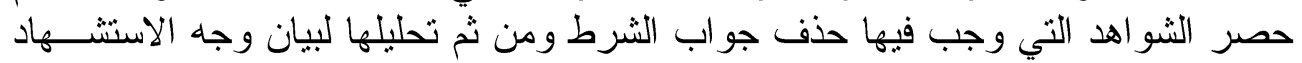

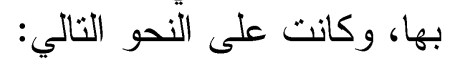

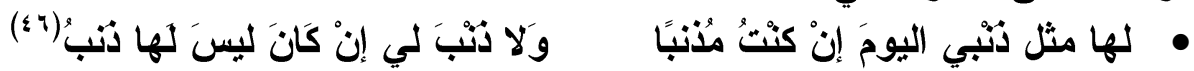

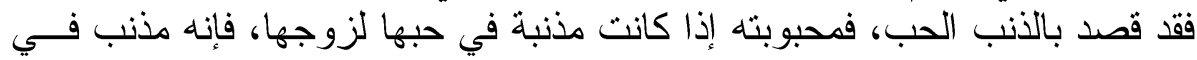

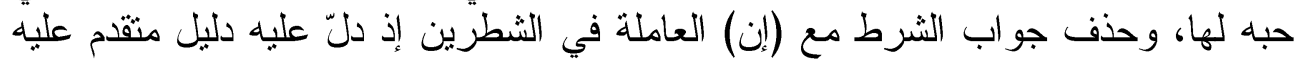

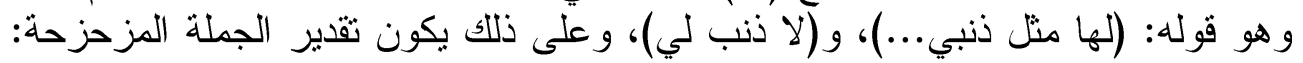

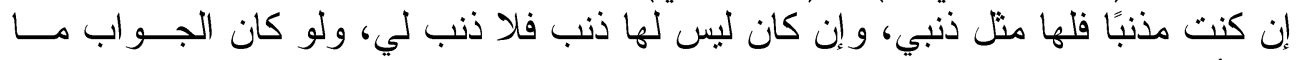

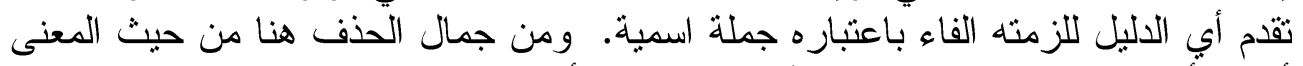

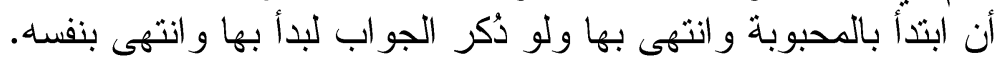

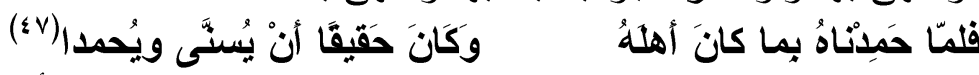

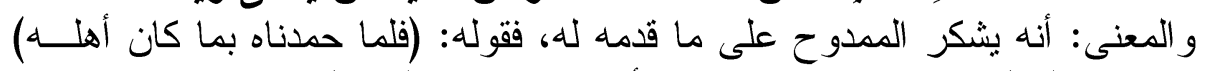

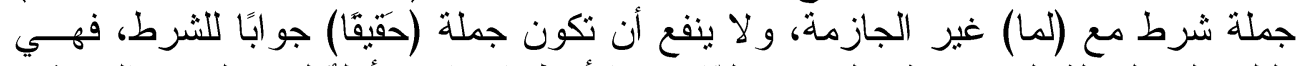

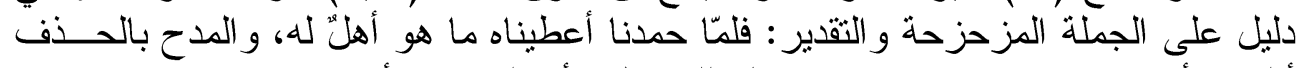

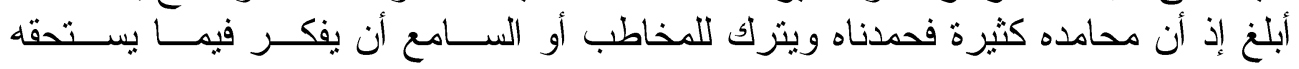

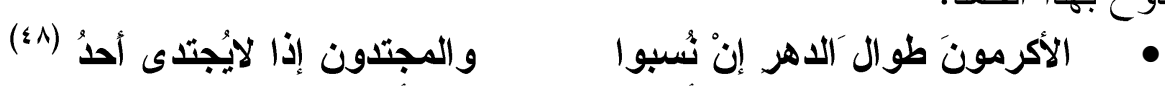

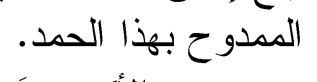

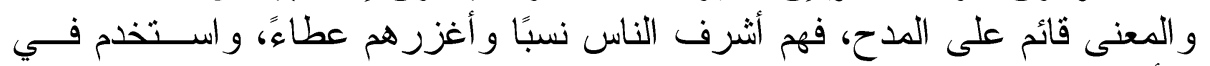

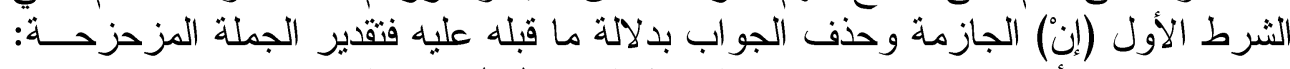

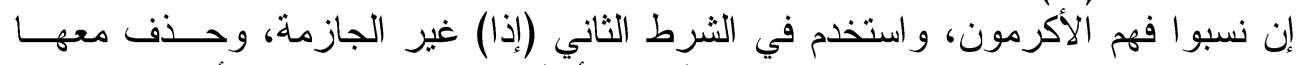

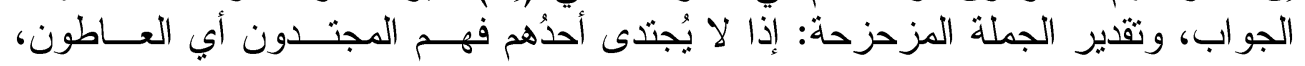


و المدح أبلغ مع الحذف فبه بترك مجالا للمخاطب بالتفكير في شرفهم و عطائهم، فبـذهب المخاطب كل مذهب في كرم نسبهم و عظيم عطائهر.

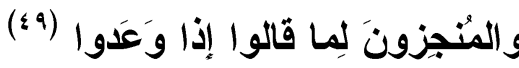

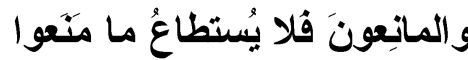

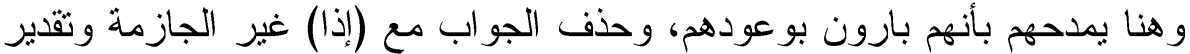

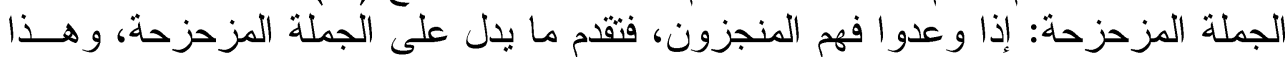

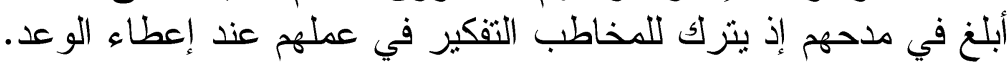

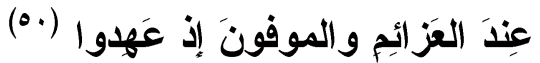

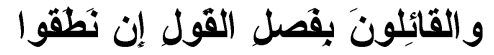

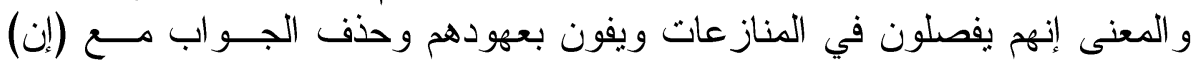

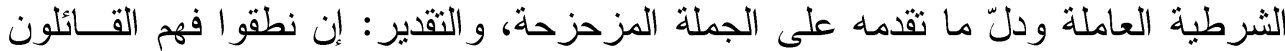

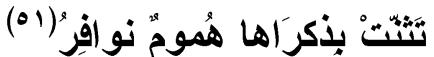

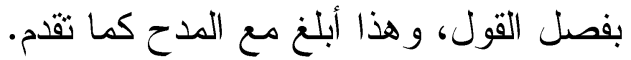

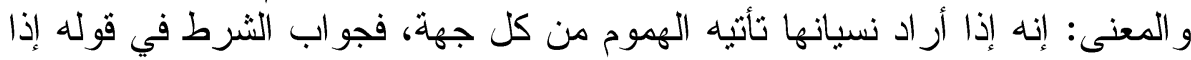

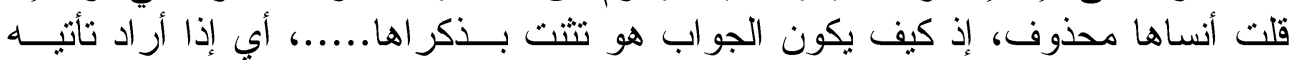

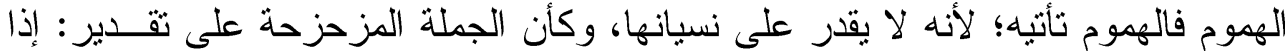

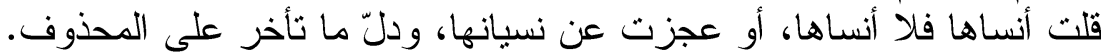

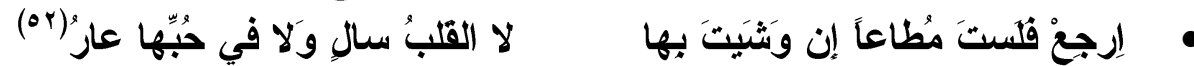

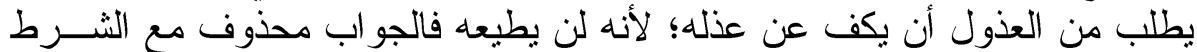

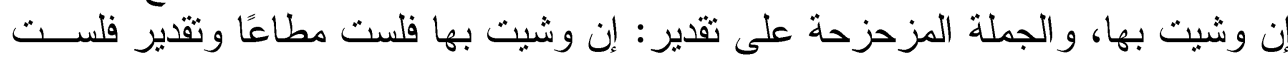

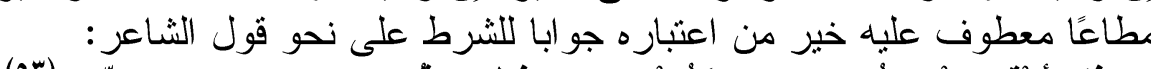

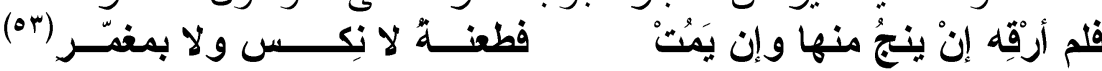

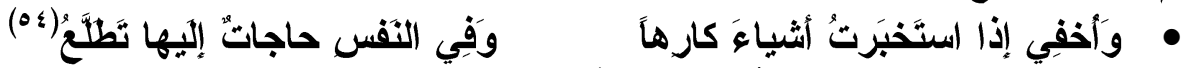

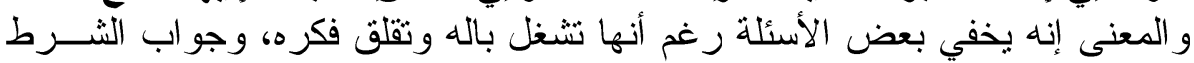

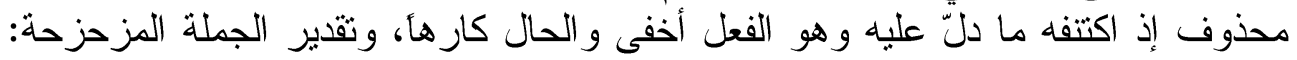

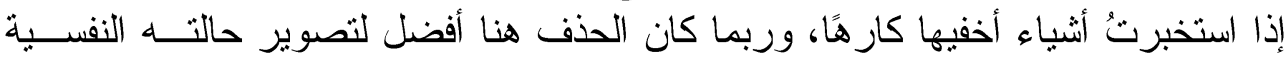

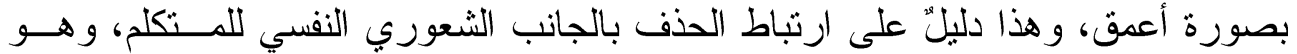

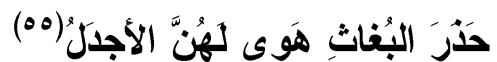

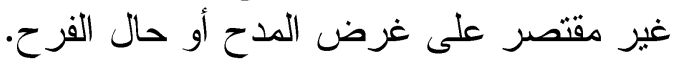

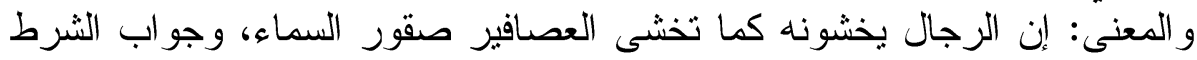

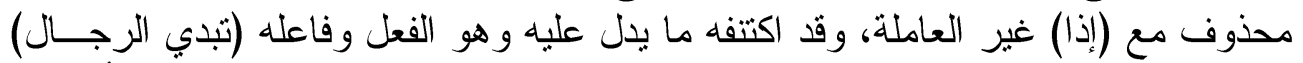

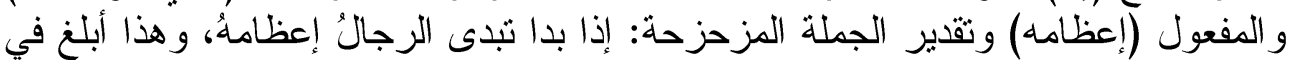

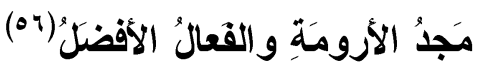
المدح.

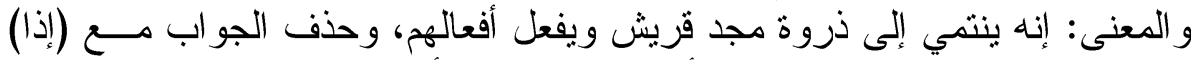

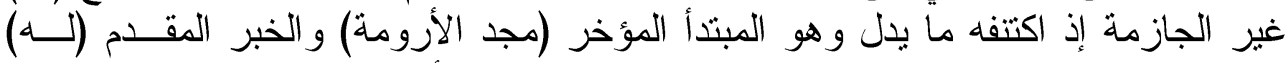
وتقدير الجملة المزحزحة: إذا نسبت قريش منهم فله مجد الأرومة.

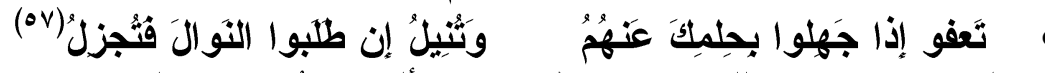

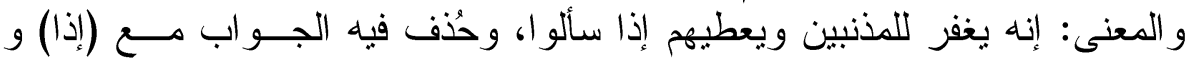
و تقدم ما يدل عليه وهو قوله (تعفو) و (تتيل) وتقدير الجملة المزحزحة: إذا جهــــوا 
تعفو ، وإن طلبو النو ال تنيلُ فتجزل و لا يصح في الأخير من حيث المعنى اعتبار فتجزل

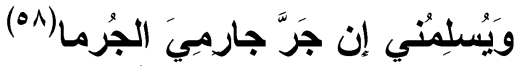

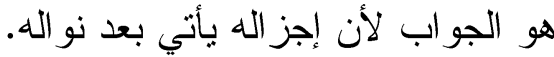

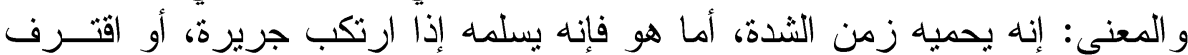

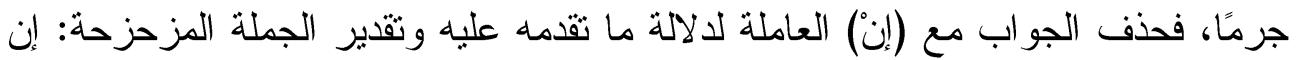

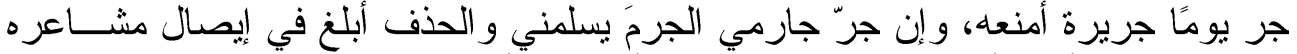

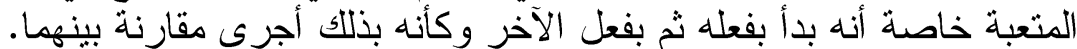

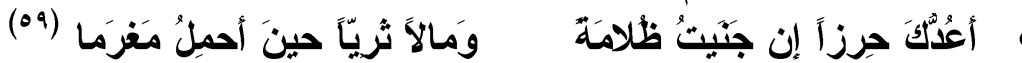

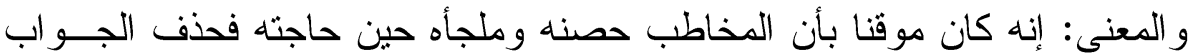

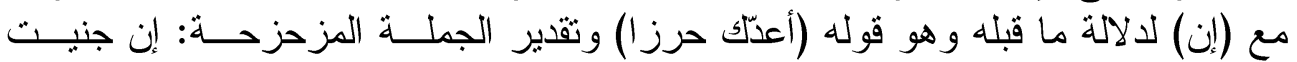

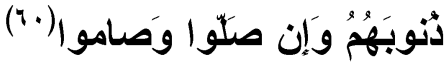

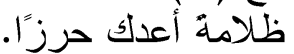

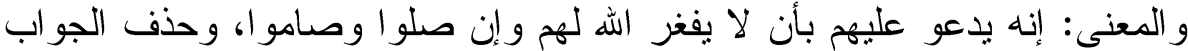

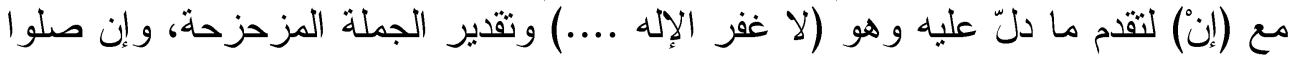

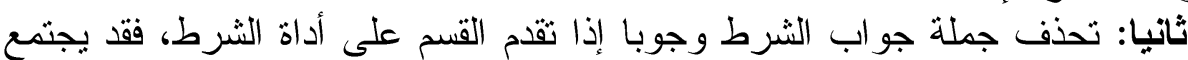

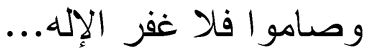

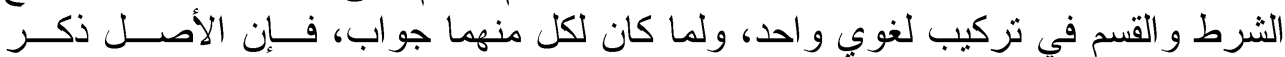

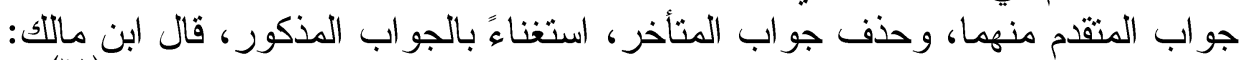

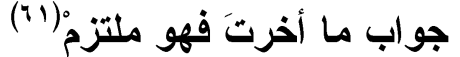

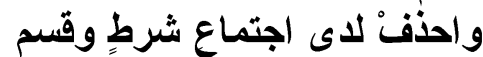

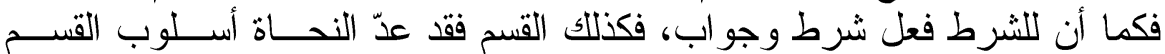

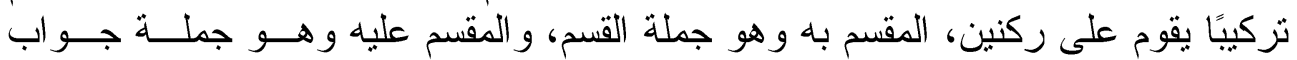

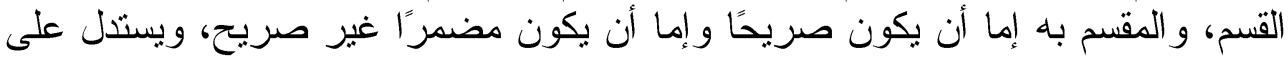

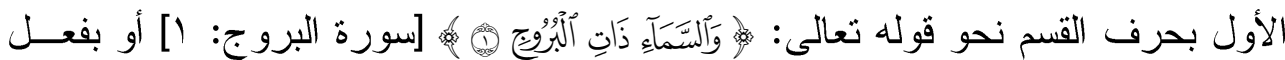

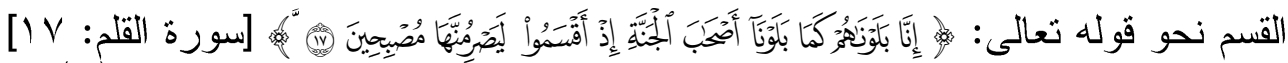

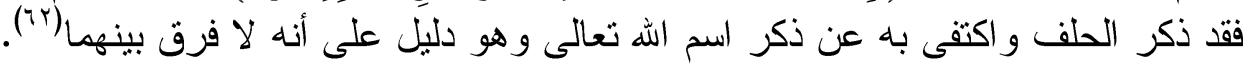

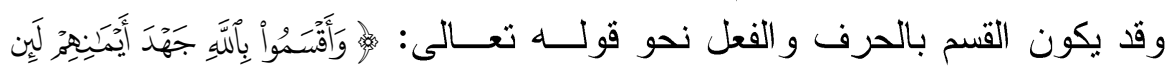

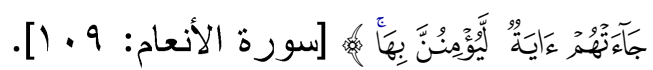

و القسم المضمر أو غير الصريح هو مالم يذكر معه المقسم به صريحًا أو ظاهرًا

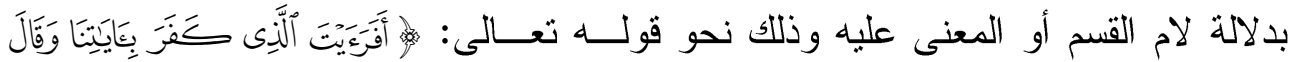

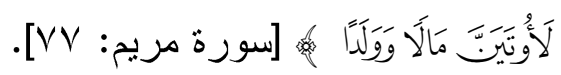

كما بِتدل باللام المقرونة بقد على القسم سو اء ذُكر أو أضمر نحو قوله تعـالى

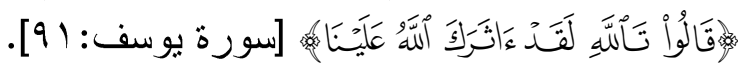

كما يستدل على القسم المحذوف باللام الموطئة للقسم وهي الاخلة على على أداة

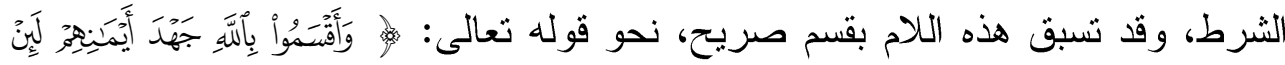

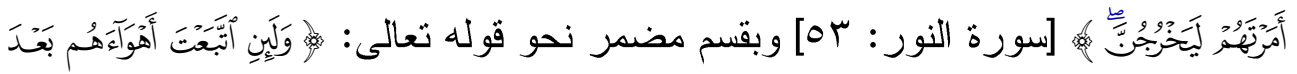




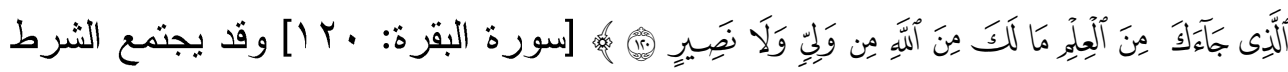

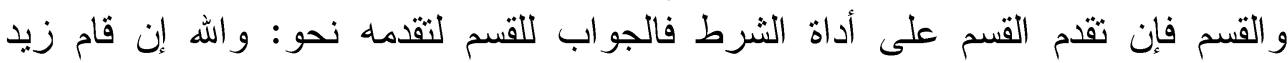

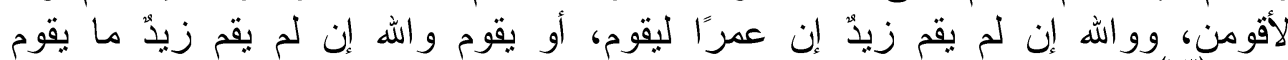

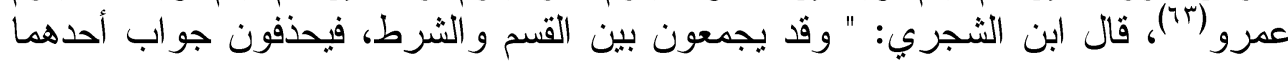

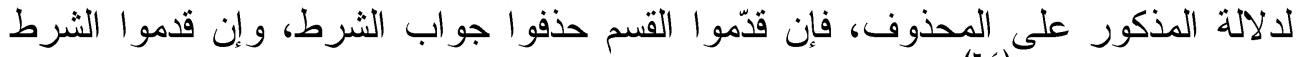

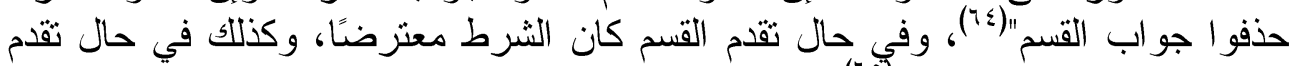

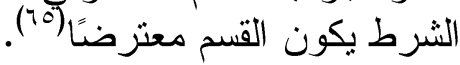

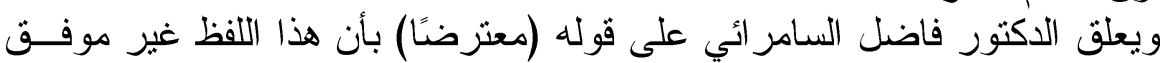

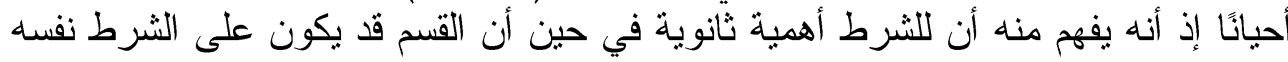

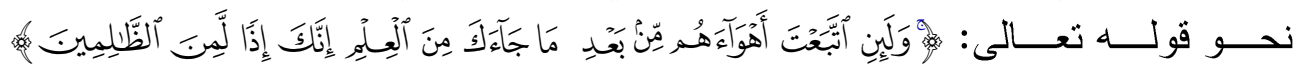

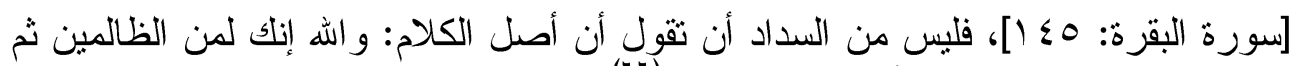

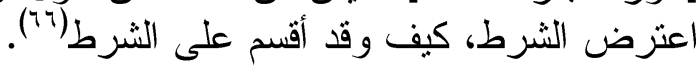

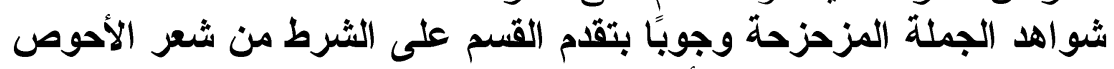

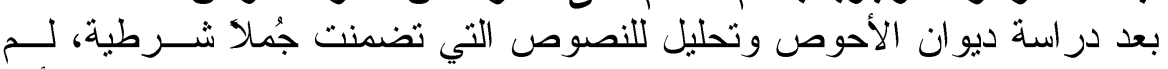
أقف سوى على شاهد و احد تضمن حذف جملة جواب الشرط وجن وجوبا لتقدم القسم على أداة الشرط:

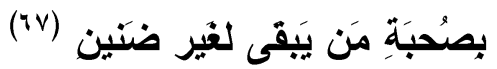

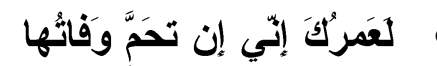

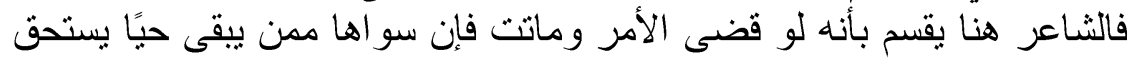

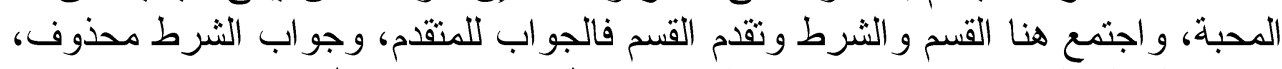
وتقدير الجملة المزحزحة ولنمة هنس جواب القسم وهو (بصحبة من ....).

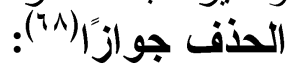

أولا: تحذف جملة الجواب جوازأ إذا وقأ وقعت جملة الشرط جوابًا لسؤال نحو: أترشد الغريب؟ فتجيب إن رأيته و التقدير : إن رأب أبته أرشده.

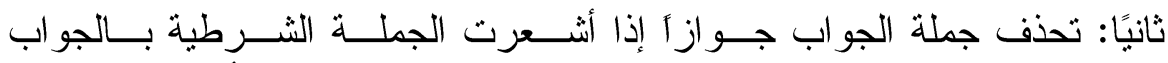

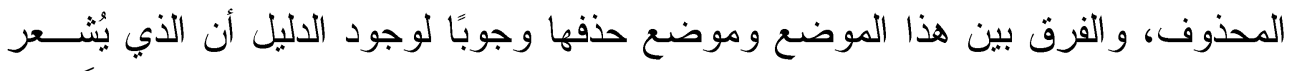

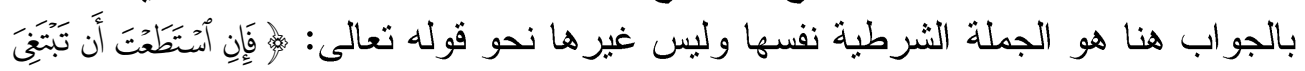

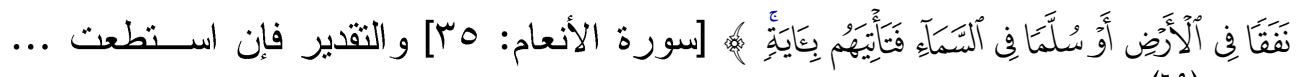

$$
\text { انتهى البحث إلى نتائج من أهمها: }
$$

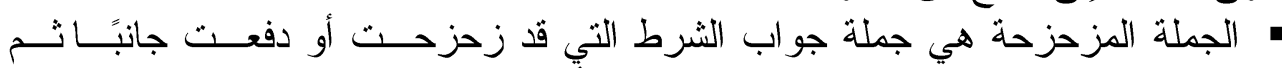

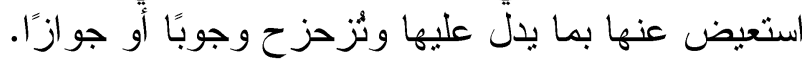

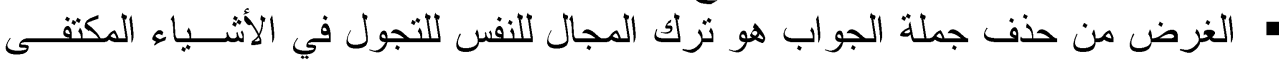

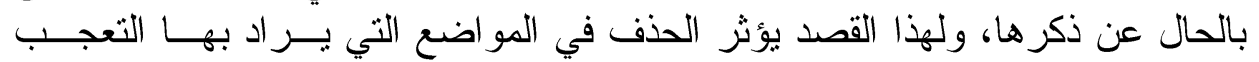
و التهويل على النفوس. • جاءت الجملة المزحزحة بدلالة دليل يسبقها أو يتأخر عنها أو يكتنفها كثيرًا في ديــوان

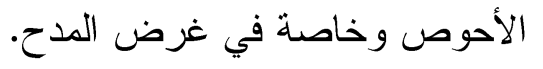


- ارتبطت الجملة المزحزحة بالجانب النفسي للثاعر فكما جاءت في المدح جاءت أيضا

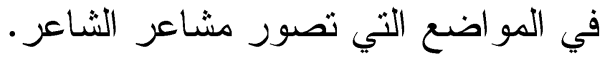

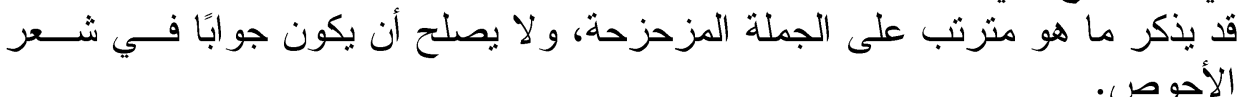

• جاءت الجملة المزحزحة وجوبًا لتقدم القسم على الشرط قليثا في شعر الأحوص.

\section{Abstract \\ The Judaized Sentence in the Diwan of Al-Ahwas Al-Ansari \\ By Fatima Abdul Rashid Muhammad Abdullah}

The research is interested in studying "Al-Jumlah AlMozahzaha woujuban" (obligatory moved away sentence) in diwan Al-Ahwas Al-Ansari (collection of poems), which is defined as jumlat jawab al-shart (the answer of a conditional clause) that has been moved away or pushed aside and indicated by evidence that cannot be an answer and is ahead of the conditional clause or came after or enclosed by it. The research covers the situations in which Al-Jumlah AlMozahzaha is obligatory or conceivably deleted providing citations from The Holy Qur'an and Arabic poetry, however, the focus of the research interest is in the applied study of $A l$ Jumlah AlMozahzaha in diwan Al-Ahwas Al-Ansari, and which is worthy of study because of the amusement and power of Al-Ahwas's characteristic who showed an elegant style and strength, and has preamble style in eulogizing, pride and praise. Some of the most important research results are:

- -The purpose of deleting the sentence is to leave the space for the soul to wander about things that are sufficiently mentioned.

- -What is a consequence of Al-Jumlah AlMozahzaha, and cannot be an answer, might be mentioned with Al-Jumlah AlMozahzaha.

- - Al-Jumlah AlMozahzaha wujuban came a lot in the poetry of Al-Ahwas and was related to the emotional side of the poet.

$$
\begin{aligned}
& \text { الـهو امش }
\end{aligned}
$$

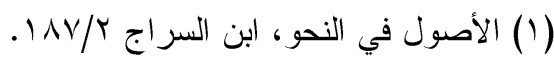

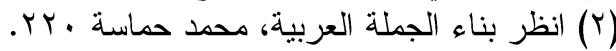

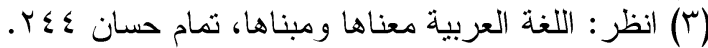

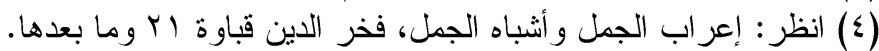

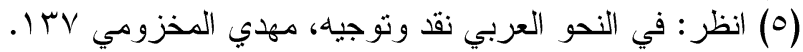

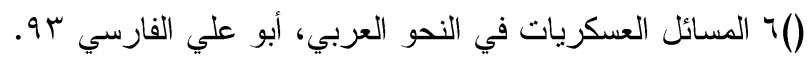

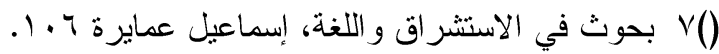




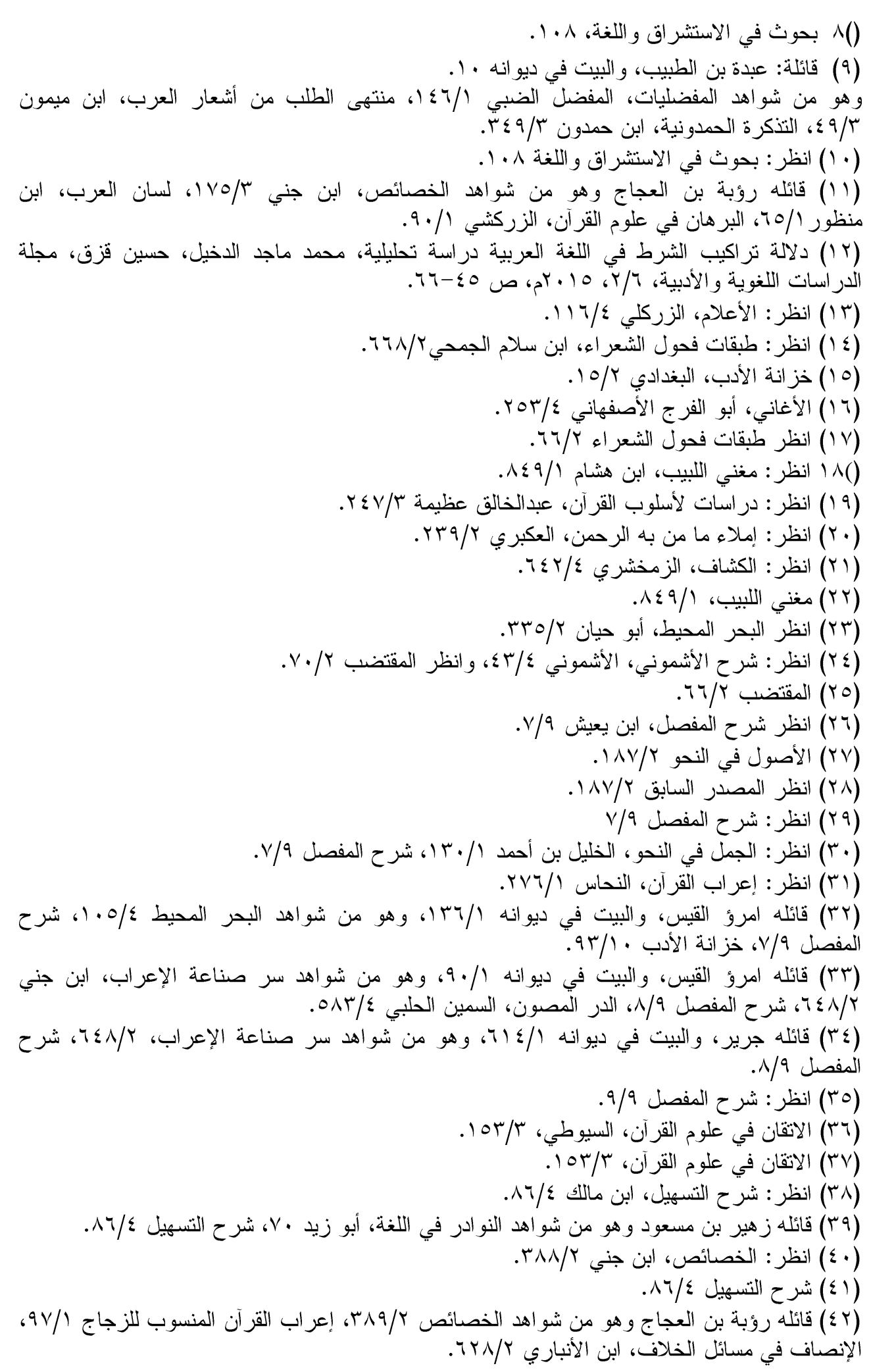




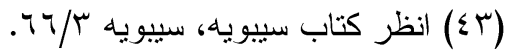

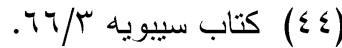

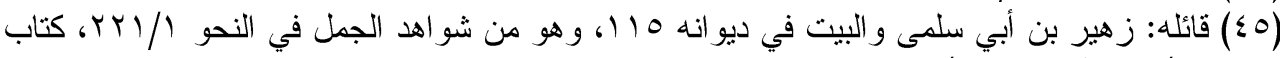

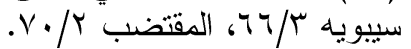

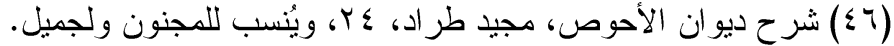

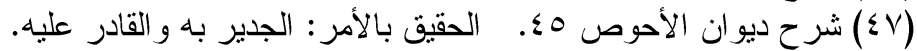

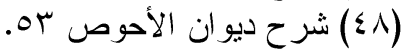

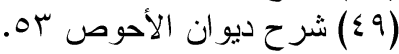

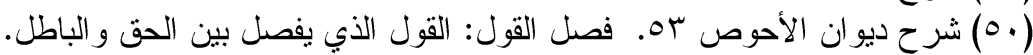

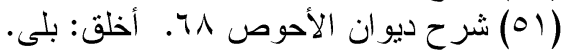

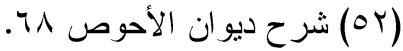

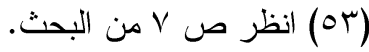

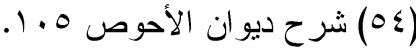

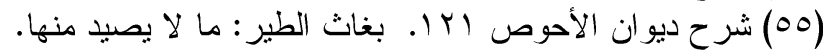

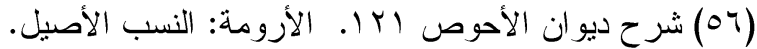

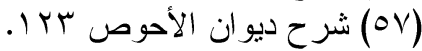

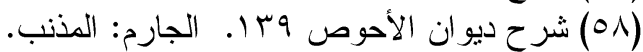

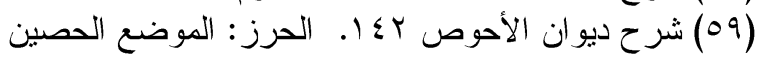

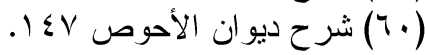

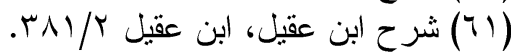

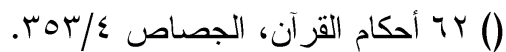

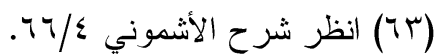

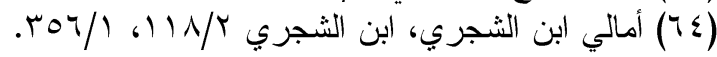

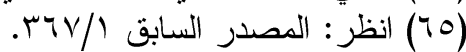

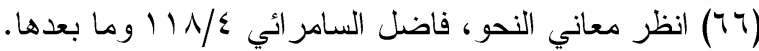

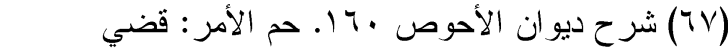

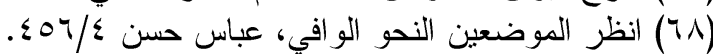

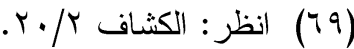

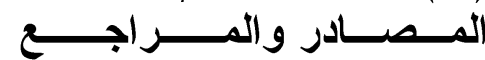

1- أحكام القزآن، أحمد بن علي الرازي الجصاص، تحقيق: محمد الصادق، بيروت، دار إحياء التراث

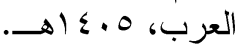

r- الأصول في النحو، أبو بكر بن سهل الهر اجه، تحقيق: عبدالحسين الفتلي، طس، بيروت، مؤسسة

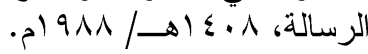

r- الأعلام قاموس تراجم لأشهر الرجال الرجال والنساء من العرب والمستعربين والمستشرقين، خير الدين

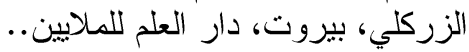

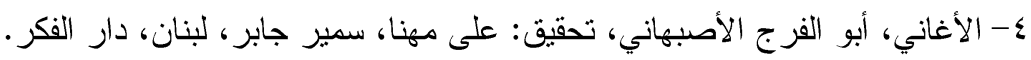

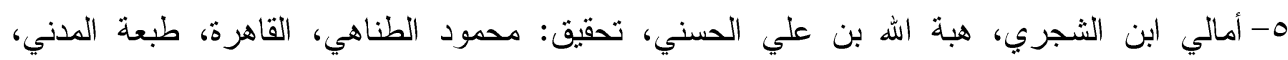

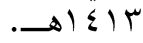

צ- الإتقان في علوم القرآن، جلال الدين السيوطي، تحقيق: سعيد المندوب، طا، لبنان، دار الفكر،

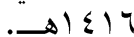


V- إعر اب الجمل و أثباه الجمل، فخر الدين قباوة، طه، حلب، دار القلم، 919 ام.

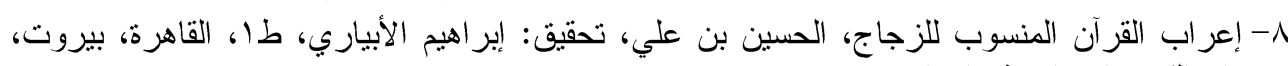

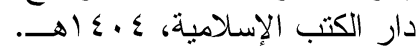

9- إعراب القرآن، أبو جعفر النحاس، تحقيق: زهير غازي زاهد، طب، بيروت، عالم الكتب، 9 ـــ (هـ| . 1911 • ا- إملاء ما من به الرحمن من وجوه الإعراب و القراءات، أبو عبداله بن الحسن العكبري، تحقيق:

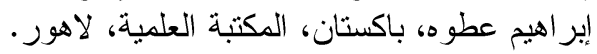

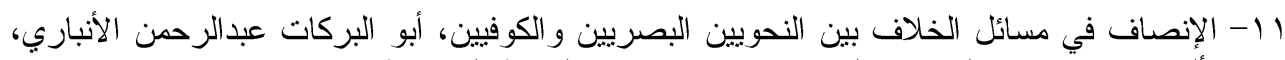

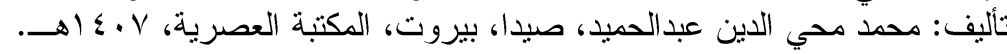

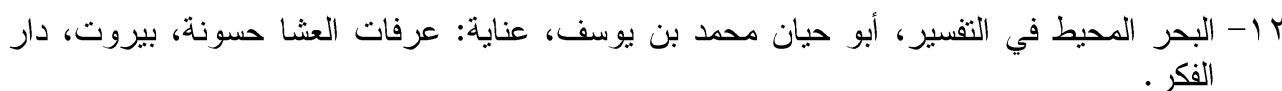

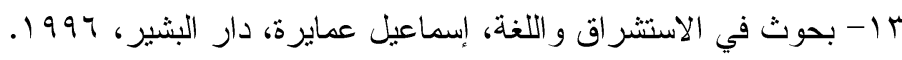
ـ ا- البرهان في علوم القر آن، محمد الزركشي، تحقيق: محمد أبو الفضل إبر اهيم، بيروت، دارئ دار المعرفة،

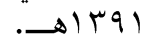

10- بناء الجملة العربية، محمد حماسة عبداللطيف، القاهرة، دار غريب، ؟ +. بام.

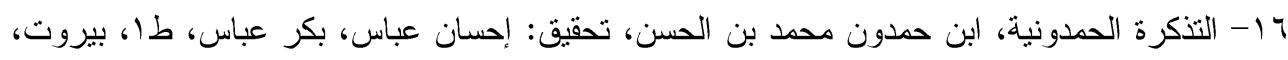

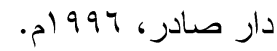

Vا الجمل في النحو، الخليل بن أحمد الفراهيدي، تحقيق: فخر الدين قباوة، بيروت مؤسسة الرسالة

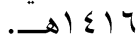

11 - خزانة الأدب ولب لباب لسان العرب، عبدالقادر البغدادي، تحقيق: محمد نبيل طريفي، أميل بديع

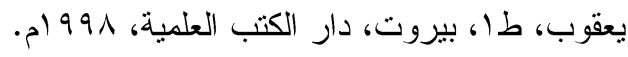

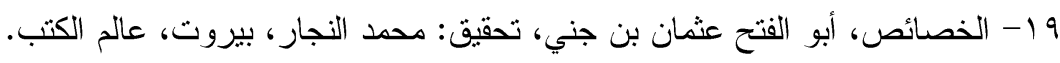

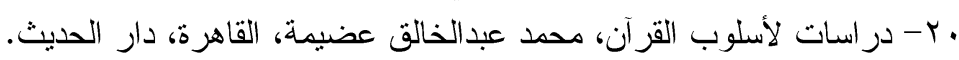

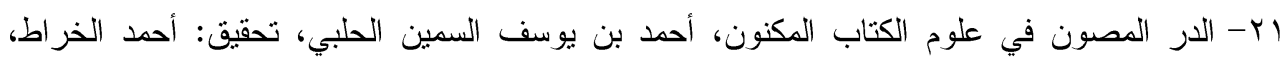

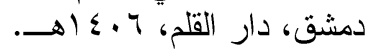

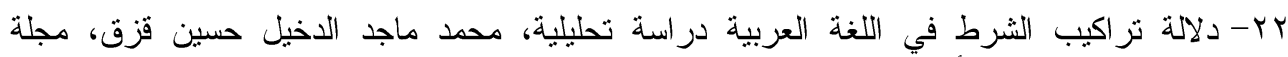

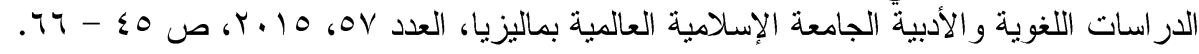

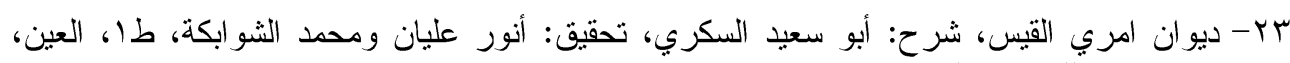

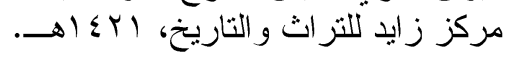

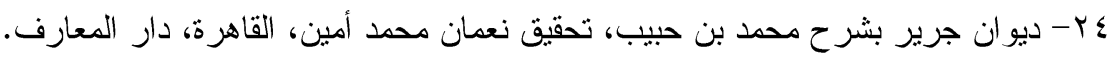

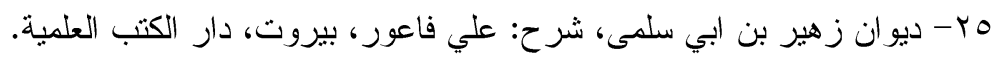

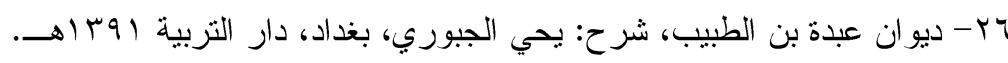

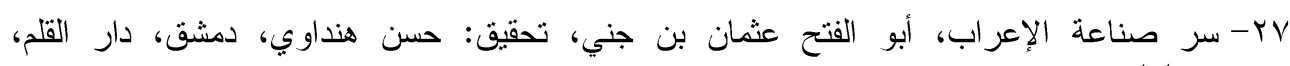
$\rightarrow$ (ه)

^ץ ^- شرح الأشموني لألفية ابن مالك، تحقيق: عبدالحميد السيد، القاهرة، المكتبة الأزهرية.

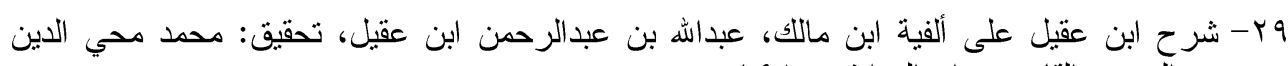

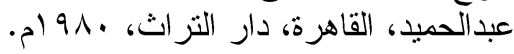
• ب-شرح التسهيل، جمال الدين ابن مالك، تحقيق: عبدالرحمن السيد ومحمد بدوي، طا، مصر، دار

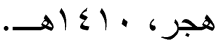


اس- شرح ديو ان الأحوص، تقديم: مجيد طر اد، طا، بيزوث، دار الكتاب العربي، 10 (اهـــ r r- شرح المفصل، موفق الدين ابن يعيش، بيروت، عالم الكتب.

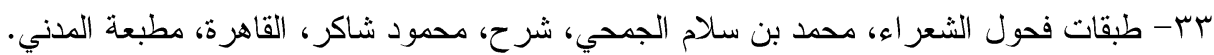

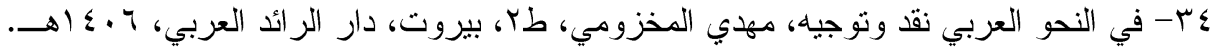

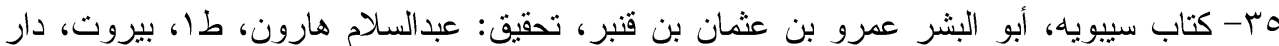
الجيل.

بس- الكثاف عن حقائق التنزيل وعيون الأقاويل في وجوه التأويل، محمود الزمخشري، طا، بيروت،

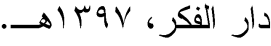

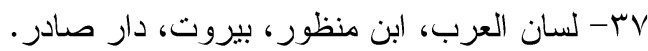

^ץ- اللغة العربية معناها ومبناها، د. تمام حسان، الدار البيضاء، دار التقافة، ؟9 9 ام.

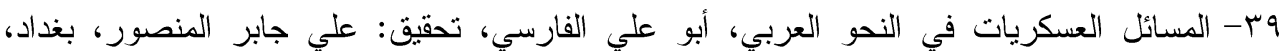

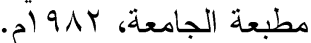

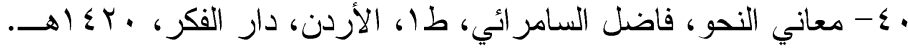

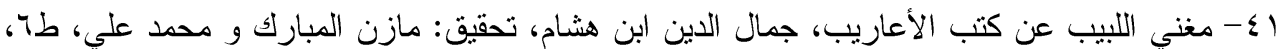

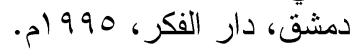

r - المفضليات، المفضل الضبي، تحقيق: أحمد محمد شاكر، عبدالسلام هارون، طج، بيروت، المكتبة التجارية.

بـ- المقتضب، أبو العباس محمد بن يزيد المبرد، تحقيق: محمد عبدالخالق عضيمة، بيروت، عالم الكتب.

ـ ـ- منتهى الطلب من أشعار العرب، محمد بن المبارك بن ميمون، تحقيق: محمد نبيل طريفي، طاه

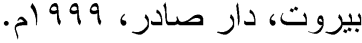

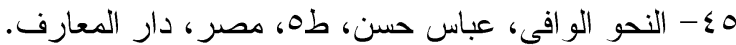

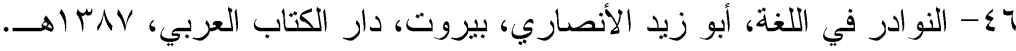

